\title{
EVALUATION OF ANTIOXIDANT FUNCTIONALITY OF FISH COLLAGEN ENZYMIC HYDROLYSATE \\ ${ }^{1}$ A.A. Abbas \\ Researcher \\ ${ }^{2}$ K. A. Shakir \\ Prof.
}

${ }^{1}$ Biotechnology Research Center, University of AL-nahrain

${ }^{2}$ Dept. Food Science- Coll. of Agric., University of Baghdad ayatadnan79@gmail.com dr_khalida55@yahoo.com

\section{ABSTRACT}

This study aimed to investigate the anti- oxidative function of catfish collagen hydrolysate in beef minced meat samples through 10 days storage at $4 \mathrm{o}$ C. Collagen hydrolysate were added to minced meat sample at two different concentrations $(50 \& 100 \mathrm{mg} / 100 \mathrm{gm})$. The experiment consist from control sample ( $C$ without additives), BHT sample ( $B$ with 200ppm butylated hydroxytoluene ), collagenase hydrolysate samples C.C.H, C.C.H $(100 \& 50 \mathrm{mg} / 100 \mathrm{gm}$ minced meat) respectively, and collagenase-trypsin hydrolysate samples C.H.T \& $_{1}$ C.H.T T $_{2}$ respectively $(50,100 \mathrm{mg} / 100 \mathrm{gm}$ minced meat $)$. Peroxide values (PV), thiobarbutyric acid TBA, free fatty acid (FFA), pH, total volatile nitrogen TVN values and total plate count assay at $0 ., 3,7 ., 10$ days were determined . PV of the BHT, C.C.H, C.H.T 2 , C.C.H 1 , C.H.T 1 groups were significantly $(\mathbf{p}<0.05)$ lower than control during storage period .Meanwhile C.C.H $\mathrm{H}_{2}$ and C.H.T 2 groups gave the lowest TBA values through the storage period . There were no significant difference found between the C.C.H $\mathbf{H}_{2}, \mathbf{C . H} . \mathrm{T}_{2}$ groups and BHT added group in all studied factors. In conclusion, the fish collagen enzymatic hydrolysates are a promising natural antioxidant and good alternative for synthetic antioxidant.

Keywords:, skin, minced meat, $\mathrm{PV}$, free fatty acid, total volatile nitrogen

*Part of Ph.D Dissertation of the $1^{\text {st }}$ author

عباس وشاكر

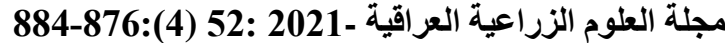

تقييم الفعالية المضادة للاكسدة للمتحلات الانزيمية لكولاجين السمك

$$
\begin{aligned}
& \text { خالاة عبد الرحمن شاكر } \\
& \text { جامعة بغداد/ كلية علوم الهندسة الزراعية }
\end{aligned}
$$

$$
\begin{aligned}
& \text { ايات عدنان عباس } \\
& \text { جامعة النهرين/مركز بحوث التقنيات الاحيائية }
\end{aligned}
$$

المستخلص

تهاف الدراسة الى تقدير الفعالية المضادة للأكسدة لمتحلات كولاجين جلد سمك الجري في نماذج اللحم المثروم خلال مدة خزن 10 أيام

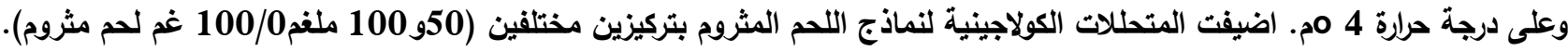

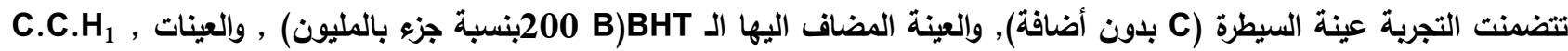
المضافة اليها (50و C. C. H2 , C.H.T1 \& C.H.T2 ( المضاف اليها متحلات الكولاجين ( المحضرة باستعمال الكولاجينييز والتربسين)بنفس التراكيز المشار اليها اعلاه على التوالي. قدرت قيمة البيروكسيد , TBA , الاحماض الدهنية الحرة , الرقم الهيدرجيني, النتروجين الكلي

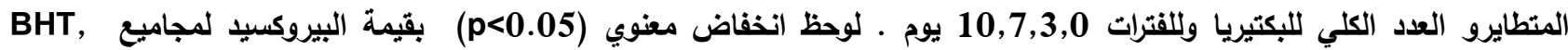
C.H.T و C.C.C.H مقارنة بعينة العيطرة خلال مدة الخزن. كما شهدت المجاميع C.H , C.H.T2, C.C.H 2 , C.H.T انخفاضا في قيم TBA خلال فترة الخزن. ولم يلاحظ فروقات معنوية بين مجاميع C.H.T2,C.C.H2 و المدروسة. نستتتج مما ورد ان متحلات كولاجين السمك الانزيمية تعد مضادات اكسدة طبيعية واعدة ويديل جيد عن المضادات الصناعية.

الكلمات المفتاحية: الجلا, اللحم المثروم , الرقم البيروكسيدي ,الاحماض الدهنية الحرة, النتروجين الكلي المتطاير. *جء من اطروحة دكتوراه للباحث الاول. 


\section{INTRODUCTION}

Fish processing wastes are a promising source for collagen. The latter is the most abundant protein constitute about $30 \%$ of total protein in animal tissue. The word collagen is derived from Greek word Kolla (glu) and genos (formation). It is well known that most of collagen is derived from Pig \&Cow skins. Collagen has a wide application in biomedical and pharmaceutical application. Additionally, gelatin, partially hydrolyzed form of collagen found wide application in food \& packaging industries for light sensitive coating (30). Because of the outbreak of certain animal disease, the use of collagen derived from Cow \& Pig skin have faced restriction. Moreover, many people around the world don't accept animal based product because of religious reason, Muslim and Jews do not consume Pig related food (21).Therefore fish collagen is the best alternative since it has a higher biological value, high essential amino acid content and low hydroxyproline content as compared to animal collagen. Fish processing by product such as skin, bone, scales \& fins are the promising sources as well as underutilized fish species of collagen. Sudeepa et al.(34) stated that India generates more than 2 million metric tons of waste every years, while. Shahidi (31) mentioned previously, the processing discards from fisheries for about $70-85 \%$ of the total weight of catch, these waste generally dumped in-land or hauled into ocean, so pose environmental problems for seafood processing. During the processing and filleting of fish, the skin constitutes a fairly large potential source of collagen, hence researchers focus on alternative sources of collagen which are marine sources $(17,42)$. Enzymatic hydrolysis of the proteins is a way of bioactive peptide production from marine products (14). Some researches about the usage of different protein hydrolysates from marine products focused on their potential antioxidant activities in food systems (19). Some synthetic antioxidants like butylated hydroxytoluene (BHT) and butylated hydroxyanisole (BHA) have long been used in the food industry for retarding or inhibiting the lipid oxidation (20). Their instability, and because of a suspected action as promoters of carcinogenesis, usually the consumer avoid to purchase products produced by synthetic additives and prefer foods with natural additives (24). The aim of the current study is to evaluate the antioxidant functionality of fish skin collagen hydrolysate as natural additives in minced meat (obtained from local butcher shops in Baghdad) over storage time at $4 \mathrm{C}$ by determining the peroxide value (PV), thiobarbutyric acid (TBA), free fatty acid (FFA), $\mathrm{pH}$, total volatile nitrogen (TVN) .

\section{MATERIALS AND METHODS}

Minced beef from the leg muscle of a calf, age one and half year old, beside fat were purchased from local market in Baghdad, and transferred to the laboratory in an icebox then, minced using mincing device (Gosonic, China 1800 w Max) . mixed 1.800 $\mathrm{g}$ with $200 \mathrm{~g}$ fat The minced meat and fat samples were mixed very well and divided in to six portions (100 g each) in duplicate. For control group (C) without any additives comparison groups(A) with 200 ppm BHT , collagenase - collagen hydrolysate group (C.C. $\mathrm{H}_{1}$, C.C. $\left.\mathrm{H}_{2}\right)$ with 50mg and 100mg respectively and trypsin - collagenase collagen hydrolysate group (C.H.T 1 , C.H.T 2 ) with $50 \mathrm{mg}$ and $100 \mathrm{mg}$ respectively.

\section{Preparation of skin collagen}

Fish collagen was extracted from catfish (Silurus triostegus ) waste. the skin cut with a pair of scissors into small pieces of about 0.5 $\mathrm{cm}$ in length according to (7) method. In order to remove the non-collagenous proteins, the skin of catfish was mixed separately with $0.1 \mathrm{M} \mathrm{NaOH}$ at a solid to alkali solution ratio of $1: 8(\mathrm{w} / \mathrm{v})$, and stirred continuously for $6 \mathrm{~h}$ at $4{ }^{\circ} \mathrm{C}$. The alkali solution was changed every $3 \mathrm{~h}$., then the skin defatted by soaking in $10 \%$ n- butane (overnight). Skin was washed with cold water until neutral $\mathrm{pH}$ Then soaked in $1.5 \%$ acetic acid with a solid to solvent ratio of 1:2 (w/v) for $72 \mathrm{~h}$., followed by pepsinassisted extraction for collagen using pepsin $(0.1 \%)$ for 3 days at $4{ }^{\circ} \mathrm{C}$ with slow agitation.

\section{Collagen hydrolysate preparation}

Skin collagen hydrolysate was prepared according to Zhang (40) method, in three separate flasks the skin collagen $(0.02$ $\%$ ) dissolved in $100 \mathrm{ml}$ phosphate buffer ( $10 \mathrm{mM} \mathrm{pH} 7.8)$ at $37^{\circ} \mathrm{C}$, collagenase $(1 \%)$ was added to one flask and left for $30 \mathrm{~min}$, and collagenase +trypsin (1\%) were added to 
another flask and held for 90 min.at ( $37^{\circ}$ C) , after that the hydrolysis process was stopped by raising the temperature to $90^{\circ} \mathrm{C}$ for $10 \mathrm{~min}$., cooled to $5^{\circ} \mathrm{C}$, centrifuged at $5000 \mathrm{xg}$ for $30 \mathrm{~min}$. The supernatant was concentrated by rotary evaporator. lyophilized and kept in tied container at $-18{ }^{\circ} \mathrm{C}$. samples of minced meat were prepared in four groups, first group represent the control sample, the $2^{\text {nd }}$ group mixed with BHT added at (200 ppm), the $3^{\text {rd }}$ group contained collagenase- assisted hydrolysate in two concentrations $(50 \& 100$ $\mathrm{mg} / 100 \mathrm{~g}$ ), and the last group was minced meat sample with the above mentioned concentration of collagenase-trypsin assisted collagen hydrolysate. Each group (100 g ) mixed by hand for 10 minutes. and rounded, then placed in plastic bags, sealed and stored at $4 \pm 1{ }^{\circ} \mathrm{C}$ for 10days. $\mathrm{pH}$, Peroxide value ( PV), TBA, FFA,TVN and TPC tests were done after $(0,3,7,10$ day). The experiment was designed with two replicates.

\section{pH measurement}

Five grams of sample were homogenized with $20 \mathrm{ml}$ distilled water in a blender for $30 \mathrm{~s}$ then filtered. The $\mathrm{pH}$ value of the filtrate was determined using a digital $\mathrm{pH}$ meter standardized at $\mathrm{pH} 4$ and 7 (28).

\section{Fat content}

According to the soxhlet extraction method of AOAC international (6). The percentage of fat in the sample was calculated using the following equation:

$\%$ Fat $=$ Post extraction Flask Wt. $(\mathrm{g})-$ Pre extraction Flask Wt. (g) / Wet Sample Wt. (g) x 100

\section{Peroxide value determination}

The modified International Dairy Federation (IDF) standard method was used to determine the peroxide values of all samples. The lipid samples (< $0.01-0.3) \quad \mathrm{g}$ was extracted according to (32). The peroxide value (PV) was determined according to Sallam et.al method (27). PV was calculated by the following equation and expressed as milliequivalent peroxide per kilogram of sample:

$\mathrm{PV}(\mathrm{mEq} / \mathrm{kg})=(\mathrm{V} \times \mathrm{N}) / \mathrm{W} \times 1000$

Where

$\mathrm{V}$ : volume of titration $(\mathrm{ml})$,

$\mathrm{N}$ : normality of sodium thiosulfate solution (N 0.01)

$\mathrm{W}$ : sample weight $(\mathrm{g})$.
Thiobarbutyric acid value (TBA): The TBA values were determined according to Witte et al., method (39) and expressed as mg malonaldehyde per $\mathrm{kg}$ meat, which was calculated as follows.

TBA value (mg MDA/kg meat) $=50 \times$ [abs. sample - abs. blank] / ( g) of sample .

\section{Free fatty acid value}

Free fatty acid (FFA) value was determined according to Rukunudin et al. method (24). The FFA value was calculated using the following equation:

FFA $(\%)=(\mathrm{mL}$ titration of $\mathrm{KOH} \times$ Normality $\mathrm{KOH} \times 28.2) /(\mathrm{g})$ of sample

Determination of total volatile nitrogen (TVN): This experiment was conducted according to the procedure adopted by FAO (11) and the TVN calculated as follow:

TVN mg/100 $\mathrm{g}=26088\left(2-\mathrm{t}_{1}\right)$.

Where: (t1) volume of $\mathrm{NaOH}$ used in titration

Microbiological analysis: Total plate count (TPC) examination was carried out according to (2).

Serial dilution: This step carried out according to ISO (13). Dilution of $\left(10^{-1}, 10^{-3}\right.$, $10^{-5}$, and $10^{-7}$ ) were used for TPC assay.

\section{Statistical analysis}

The program of Statistical Analysis System SAS (29) was employed to perform the different factors in investigation parameters. The LSD (least significant difference) test has been employed to significant compare within the means of this investigation

\section{RESULTS AND DISCUSSION}

pH value: The changes in $\mathrm{pH}$ values of the control and treated samples under storage at $4 \pm 1^{\circ} \mathrm{C}$ for $0,3,7$, and 10 days are represented in table 1 . It has been seen that the $\mathrm{pH}$ of samples declined significantly $(\mathrm{p} \leq 0.05)$ during the storage period. 
Table 1. Effect of collagen hydrolysates on pH of beef minced meat samples during storage period at $4 \pm 1^{\circ} \mathrm{C}$

\begin{tabular}{|c|c|c|c|c|c|}
\hline \multirow[t]{2}{*}{ Treatmen } & \multicolumn{4}{|c|}{$\begin{array}{c}\text { pH } \\
\text { Storage period ( day) }\end{array}$} & \multirow[t]{2}{*}{$\begin{array}{c}\text { LSD } \\
\text { value }\end{array}$} \\
\hline & 0 & 3 & 7 & 10 & \\
\hline Control & 6.0 & 5.8 & 5.7 & 5.4 & 0.581* \\
\hline BHT & 6.2 & 6.1 & 6.0 & 5.9 & 0.358 NS \\
\hline C.C.H & 6.1 & 5.9 & 5.7 & 5.6 & $0.495 *$ \\
\hline C.C. $\mathbf{H}_{2}$ & 6.0 & 5.9 & 5.8 & 5.7 & $0.366 \mathrm{NS}$ \\
\hline C.H.T & 6.0 & 5.9 & 5.8 & 5.7 & $0.366 \mathrm{NS}$ \\
\hline $\begin{array}{l}\text { C.H.T } \\
\text { LSD }\end{array}$ & 6.1 & 6.0 & 5.9 & 5.8 & 0.372 NS \\
\hline Value & $\begin{array}{c}0.461 \\
\text { NS }\end{array}$ & $\begin{array}{c}0.409 \\
\text { NS }\end{array}$ & $\begin{array}{r}0.387 \\
\text { NS }\end{array}$ & $\begin{array}{r}0.437 \\
\text { NS }\end{array}$ & ----- \\
\hline
\end{tabular}

control (C), collagenase hydrolysed collagen $(50 \&$ $100 \mathrm{mg} / 100 \mathrm{~g}$ meat $)\left(\right.$ C.C.H $\mathbf{H}_{1}$, C.C.H $\mathrm{H}_{2}$, collagenase -

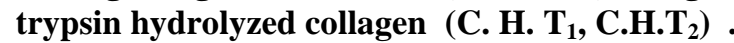
* $(\mathbf{P} \leq \mathbf{0 . 0 5})$.

The $\mathrm{pH}$ values at the beginning of the storage for the sample under study ranged from 6-6.2 while by the end of storage period ranged from 5.4-5.9 . The decreases in experimental samples $\mathrm{pH}$ values significantly different as compared to control, while the differences between the BHT treatment and the collagen hydro lysate added samples were in significant $\mathrm{P} \leq 0.05$. In another word the effect of experimental hydrolysate on minced meat samples $\mathrm{pH}$ values were comparable to the BHT. The increase or decrease of meat $\mathrm{pH}$ values could influences the rate of oxidation as well as the microbial shelf life and drip loss and vice versa (23). This result might be due to loss of minerals and small protein compounds as exudates from beef samples, causing ionic imbalance in the beef muscle which resulted in a decreased $\mathrm{pH}$ (36). The $\mathrm{pH}$ value also might be decreased in the current study due to increase in glycolysis with phosphorylase activation (8). Additionally, such decline in $\mathrm{pH}$ might be due to the action of psychrophilic bacteria which ferment the carbohydrate present in the ingredients used in the formulation of the product.

\section{Peroxide value PV}

Table 2 summarize the results of $\mathbf{P V}$ for the experimental samples and the control samples besides the comparison sample (BHT added at $200 \mathrm{ppm})$.
Table 2. Peroxide value (PV) (mEq /Kg for beef minced meat samples during storage period at $4 \pm 1^{\circ} \mathrm{C}$.

\begin{tabular}{|c|c|c|c|c|c|}
\hline \multirow[t]{2}{*}{ Treatment } & \multicolumn{4}{|c|}{$\begin{array}{c}\text { PV (mEq /Kg) } \\
\text { Storage period ( day) }\end{array}$} & \multirow[t]{2}{*}{$\begin{array}{l}\text { LSD } \\
\text { value }\end{array}$} \\
\hline & $\mathbf{0}$ & 3 & 7 & 10 & \\
\hline Control & 0.42 & 9.67 & 17.99 & 34.80 & 4.662* \\
\hline BHT & 0.35 & 2.83 & 9.33 & 16.66 & 3.271* \\
\hline C.C.H $H_{1}$ & 0.30 & 6.30 & 12.82 & 25.47 & 4.392* \\
\hline C.C. $\mathrm{H}_{2}$ & 0.33 & 3.66 & 11.01 & 20.00 & 4.152* \\
\hline C.H.T & 0.30 & 5.0 & 12.31 & 24.25 & $5.138 *$ \\
\hline C.H.T & 0.30 & 3.33 & 10.16 & 19.93 & $4.509 *$ \\
\hline \multirow[t]{2}{*}{ LSD } & 0.166 & 2.371 & 2.703* & 4.632 & ----- \\
\hline & \multicolumn{2}{|c|}{ Value } & NS & & \\
\hline
\end{tabular}

control (C), collagenase hydrolysed collagen $(50$ \& $100 \mathrm{mg} / 100 \mathrm{~g}$ meat) (C.C.H1, C.C.H.2), collagenase trypsin hydrolyzed collagen (C. H. T, C.H.T . $_{1}$.* (P $\leq$ 0.05).

In general, peroxide values significantly higher in the control sample than in the other samples through storage time, Although peroxide values increased with increasing storage time in all samples, the most potent antioxidant (i.e., the treatments that recorded the lowest peroxide values) were C.C. $\mathrm{T}_{2}$.C. C. $\mathrm{H}_{2}$,C.H. $\mathrm{T}_{1}$, C.C. $\mathrm{H}_{1}$. as compared to BHT sample. BHT and C.C.H2, C.H.T 2 groups were found to show a significantly $(\mathrm{p} \leq 0.05)$ lower value than the other groups. Sudeepa et al. (34), reported that the amino acids which have active side chains (sulfhydryl, thioether, amino group, imidazole, and indole ring) are sensitive to the oxidation due to the oxidizing lipids. Especially cysteine, methionine, lysine, arginine, histidine and tryptophan residues and also valine serine and proline are common targets of reactive oxygen species (15).

\section{Thiobarbituric acid (TBA)}

Changes in values of thiobarbituric acid (TBA) of control and treated beef minced meat samples during storage at $4^{\circ} \mathrm{C}$ for 10 days are given in table 3 . The results showed that the antioxidant concentration and storage period had significant effects on TBA values * $(\mathrm{P} \leq 0.05)$. During storage at $4 \pm 1^{\circ} \mathrm{C}$, TBA values in control samples started to increase from 0.22 (day 0) to 0.915 (day 7) and increased rapidly after 10 days of storage at 4 $\pm 1^{\circ} \mathrm{C}$ to reach $2.02 \mathrm{mg}$ malonaldehyde (MDA)/ $\mathrm{kg}$ meat. While, samples of beef minced meat treated with $50 \mathrm{mg}$ collagen hydrolysate (C.C.H $\mathrm{H}_{1}$ had lower TBA values $(0.2$ and $0.65 \mathrm{mg} / \mathrm{MDA} / \mathrm{kg}$ meat) for 0 and 7 days respectively, followed by BHT treatment, 
which were $0.95 \mathrm{mg} \mathrm{MDA} / \mathrm{kg}$, after 10 days of storage. The increase in TBA values in all treatments for the period of cold storage attributed to the lipid oxidation. Treatments with $100 \mathrm{mg}$ of collagen hydrolysate (C.C. $\mathrm{H}_{2}$, C. $\mathrm{H} . \mathrm{T}_{2}$ ) were superior in retarding oxidative process in meat samples, since these two treatments were kept TBA values within the consumption level ( $>2 \mathrm{mg} \mathrm{MDA} / \mathrm{kg}$ meat) after 10 days of cold storage. Raharjo, \& Sofos (22) mentioned that the values of TBA are an indicator of lipid oxidation in meat products during storag. Verme \& Sahoo (35) indicated that if the TBA value increased to more than 2 mg MDA/kg meat, the meat considers as low quality(rejected). The control samples and treatment C.C. $\mathrm{H}_{1}$ gave TBA value more than $2 \mathrm{mg} \mathrm{MDA} / \mathrm{kg}$ beef minced meat after 10 days storage. This result may be attributed to the amount of hydroxyl groups within the structures of antioxidants agent present in hydrolysate mainly hydroxyl cycle in amino acids such as proline, hydroxyproline. It is assumed that inhibition of lipid oxidation and hydrogen donor ability is enhanced with the increasing amount of hydroxyl groups - According to (8), which recommended that TBA of fresh meat should not exceed 0.9 $\mathrm{mg} / \mathrm{Kg}$, all the examined meat samples were accepted and fit for consumption where their TBA contents did not exceed this accepted limit .It is of great importance to mention that TBA values could be a useful quality index for the assessment of rancidity during the storage of lipid rich food. Wilson (38) mentioned that when the ratio of fat content increased in meat, the TBA value will be increased indicating probable lipids oxidation. Generally, TBA value is routinely used as index of lipid oxidation in meat and its products and the rancid flavor is initially detected in meat when TBA values lies between 0.5 and $2.0 \mathrm{mg} / \mathrm{Kg}$ (12).
Table 3. Effect of fish skin collagen hydrolysate addition on thiobarbutric acid values of beef minced meat samples during storage period at $4 \pm 1^{\circ} \mathrm{C}$

\begin{tabular}{|c|c|c|c|c|c|}
\hline \multirow[t]{2}{*}{ Treatmen } & \multicolumn{4}{|c|}{$\begin{array}{l}\text { TBA (mg MDA/Kg meat) } \\
\text { Storage period ( day) }\end{array}$} & \multirow[t]{2}{*}{$\begin{array}{l}\text { LSD } \\
\text { value }\end{array}$} \\
\hline & $\mathbf{0}$ & 3 & 7 & 10 & \\
\hline Control & 0.22 & 0.63 & 0.915 & 2.02 & $0.416 *$ \\
\hline BHT & 0.21 & 0.26 & 0.48 & 0.95 & $0.286 *$ \\
\hline C.C. $\mathrm{H}_{1}$ & 0.20 & 0.47 & 0.65 & 1.48 & $0.337 *$ \\
\hline C.C. $\mathrm{H}_{2}$ & 0.19 & 0.31 & 0.63 & 1.13 & 0.301* \\
\hline C.H.T 1 & 0.18 & 0.45 & 0.71 & 1.54 & $0.379 *$ \\
\hline $\begin{array}{l}\text { C.H.T } \\
\text { LSD }\end{array}$ & 0.20 & 0.30 & 0.55 & 1.15 & $0.305 *$ \\
\hline Value & $\begin{array}{c}\mathbf{0 . 0 7 7} \\
\text { NS }\end{array}$ & $0.187 *$ & $\begin{array}{l}0.282 \\
\text { NS } \\
\end{array}$ & $\begin{array}{l}0.297 * \\
\text { NS }\end{array}$ & ----- \\
\hline
\end{tabular}

control $(\mathrm{C})$, hydrolysed collagen with collagenase (50 \& $100 \mathrm{mg} / 100 \mathrm{~g}$ meat $($ C.C.H.1, C.C.H.2) and with added collagenase-trypsin hydrolyzed collagen $(C$. H. T $_{1}$.C.H.T )

Free fatty acids (FFA)

The results of enzymatic and non-enzymatic lipid hydrolysis usually use as lipid quality indicator. Table 4 illustrate the formation of FFA in experimental samples during storage period, the storage time and the added collagen hydrolysate concentrates were significantly reduced the FFA\% formation as compared to control sample. FFA\% for the samples under study ranged from $0.160-1.72$ at the sample preparation time and increased to be ranged $0.68-1.79 \%$ by the end of the storage period (10 days). As the results of PV and TBA test the C.C.H2 ,C.H.T2 treatments were more effective in reducing FFA formation than the others .The FFA\% for BHT treatment was $0.68 \%$ and for C.C.H2 ,C.H.T2 were $(0.76$ \& $0.70 \%$ ) respectively. Hence these treatments could be good natural alternative for synthetic antioxidant agent. Barthet et al (4) stated , FFA formation often occurs as a result of catalysis by endogenous enzymes. Whittle (37) observed that low temperature $\left(4{ }^{\circ} \mathrm{C}\right)$ in combination with $\alpha$-tocopherol acetate solutions could not stop lipid hydrolysis. Published reports on the effect of collagen hydrolysate on the FFA formation in fish are limited and this aspect needs further investigation. Sikorski et al (33) mentioned that despite the negative effect of FFA on protein solubility and texture deterioration, the formation of FFA itself does not lead to nutritional losses. The results of this study were similar to many published researches 
result $(3,5,16)$ and 18$)$ in various meat products .

Table 4. Effect of Collagen Hydrolysates on Free fatty acid (FFA) \% of beef minced meat samples during storage period $(0,3,7$, 10 days ) at $4 \pm 1{ }^{\circ} \mathrm{C}$

\begin{tabular}{|c|c|c|c|c|c|}
\hline \multirow[t]{2}{*}{ Treatment } & \multicolumn{4}{|c|}{$\begin{array}{l}\text { Free fatty acids } \\
\text { FFA \% } \\
\text { ge period ( day) }\end{array}$} & \multirow[t]{2}{*}{$\begin{array}{l}\text { LSD } \\
\text { value }\end{array}$} \\
\hline & $\mathbf{0}$ & 3 & 7 & 10 & \\
\hline Control & 0.166 & 0.443 & 0.77 & 1.79 & $0.363 *$ \\
\hline BHT & 0.169 & 0.188 & 0.45 & 0.68 & $0.259 *$ \\
\hline C.C.H ${ }_{1}$ & 0.170 & 0.29 & 0.61 & 0.91 & $0.341 *$ \\
\hline C.C. $\mathrm{H}_{2}$ & 0.160 & 0.23 & 0.52 & 0.76 & $0.217 *$ \\
\hline C.H.T 1 & 0.172 & 0.26 & 0.57 & 0.85 & $0.255 *$ \\
\hline C.H.T ${ }_{2}$ & 0.171 & 0.19 & 0.48 & 0.70 & $0.269 *$ \\
\hline LSDValue & 0.033 & $0.115 *$ & 0.142 & $0.277 *$ & ---- \\
\hline & NS & & & NS & \\
\hline
\end{tabular}

control ( $\mathrm{C}$ ), collagen hydrolysate with collagenase (50 \& $100 \mathrm{mg} / 100$ gmeat) (C.C.H.1, C.C.H.2) and samples with collagenase- trypsin collagen hydrolysate (C. H. T 1, ,C.H .T 2 ) .

$*(\mathbf{P} \leq \mathbf{0 . 0 5})$.

\section{The total volatile nitrogen ( TNV)}

The TNV amount is one of quality indicators for meat deterioration and spoilage of meat during storage period (Fan, 10). Table (5) shows the TVN value (mg N/ $100 \mathrm{~g}$ ) in the minced meat samples. The results showed that collagen hydrolysates concentration and storage period had significant effects on TVN values $(\mathrm{P}<0.05)$. For control samples the TNV values were increased from 1.13 ( 0 day) to 22.14 (10th day) and it is significantly higher than the other treatments. The TVN values for the samples with collagen hydrolysates recorded lower values in comparison to control and higher than BHT treatment. In general,at the day $7^{\text {th }}$, all examined minced meat samples TVN values were not more than 20 mg \%, which means they all accepted and fit for use where their TVN contents did not exceed the accepted limit (8). Table 5 also illustrate that at the end of the storage period (10 day), minced meat samples treated with 50 $\mathrm{mg}$ and $100 \mathrm{mg}$ collagen hydrolysates were recorded high TVN values, which were 21.28, $19.76 \mathrm{mg} \mathrm{N} / 100 \mathrm{~g}$ for C.C. $\mathrm{H}_{1}$, C.C. $\mathrm{H}_{2}$ and 21.62, $20.90 \mathrm{mg}$ N/ $100 \mathrm{~g}$ for C.H.T 1 ,C.H.T 2 respectively. This may be attributed to the degradation of protein as a result of the activity of proteolytic enzymes and the microbial content that contribute in accumulation of free nitrogen groups that might lead to higher TVN values (26).
Table 5 . Effect of Collagen Hydro lysates on total Volatile Nitrogen for beef minced meat samples during storage period at $4^{\circ} \mathrm{C}$.

\begin{tabular}{|c|c|c|c|c|c|}
\hline \multirow{2}{*}{\multicolumn{2}{|c|}{ Treatment }} & \multicolumn{3}{|c|}{$\begin{array}{l}\text { TVN (mg N/100g meat) } \\
\text { Storage period ( day) }\end{array}$} & \multirow[t]{2}{*}{$\begin{array}{l}\text { LSD } \\
\text { value }\end{array}$} \\
\hline & & \multicolumn{3}{|c|}{$\begin{array}{llll}0 & 3 & 7 & 10\end{array}$} & \\
\hline Control & 1.13 & 3.32 & 9.20 & 22.14 & 3.281* \\
\hline BHT & 1.11 & 3.50 & 8.41 & 20.73 & 2.668 \\
\hline C.C. $H_{1}$ & 1.06 & 4.50 & 9.65 & 21.28 & 2.504* \\
\hline C.C.H & 1.12 & 3.99 & 8.02 & 19.76 & $2.153 *$ \\
\hline C.H.T 1 & 1.10 & 4.87 & 7.38 & 21.62 & 2.709* \\
\hline C.H.T 2 & 1.11 & 4.21 & 6.60 & 20.90 & $2.336 *$ \\
\hline $\begin{array}{l}\text { LSD } \\
\text { Value }\end{array}$ & 0.387 & 1.792 & 2.772 & 2.062 & --- \\
\hline
\end{tabular}

control ( $\mathrm{C}$ ), hydrolyzed collagen with collagenase (50 \& $100 \mathrm{mg} / 100 \mathrm{~g}$ meat ) (C.C.H.1, C.C.H.2) and with added collagenase - trypsin hydrolyzed collagen (C.H .T 1 , C.H . T 2$) *(\mathbf{P} \leq \mathbf{0 . 0 5})$.

Total plate count: Table 4 shows the effect of different concentrations of fish collagen hydrolysate and synthetic antioxidant (BHT) on total plate count (TPC), of beef minced meat stored at $4^{\circ} \mathrm{C}$ for 10 days. Results indicated that microbial counts increased with time during the storage period. At at the beginning of the storage total plate count (TPC) of the meat samples ranged from 30 $\mathrm{X10}^{-7}$ to $37 \times 10^{-7}$ and increased to $181 \times 10^{-}$ 7 to $211 \times \mathbf{1 0}^{-7}$ after 7 days storage. It has been noticed a remarkable increase in total count, it reached to Too Numerous To Count (TNTC) after 10 days storage. This indicates that the experimental collagen hydrolysates had no antibacterial function toward Gram-positive and Gram-negative bacteria. ( 1) the result reported that the antibacterial activity of black-barred halfbeak gelatin and its hydrolysate was evaluated against three Gram negative (Klebsiella pneumonia, Salmonella enterica, and Salmonella typhi) and three Gram positive (Micrococcus luteus, Staphylococcus aureus, andBacillus cereus) bacteria, Black-barred halfbeak gelatin at $10 \mathrm{mg} / \mathrm{mL}$ exhibited a slight inhibitory activity against Gram positive $M$. luteus and $B$. cereus, with inhibitor diameter zones of $6.5 \mathrm{~mm}$ and $7.0 \mathrm{~mm}$, respectively. Increasing concentration from 10 to $25 \mathrm{mg} / \mathrm{mL}$ slightly increased activity with inhibition zone diameter reaching $8.5 \mathrm{~mm}$ and $9.0 \mathrm{~mm}$ against $M$. luteus and $B$. cereus, respectively. 
Table 6. Total Plate Count (TPC) for beef minced meat samples during storage period at $4^{\circ} \mathrm{C}$

\begin{tabular}{|c|c|c|c|c|}
\hline \multirow[t]{2}{*}{ Treatmen } & \multicolumn{4}{|c|}{$\begin{array}{l}\text { Total plate count } \\
\text { Storage period ( day) }\end{array}$} \\
\hline & $\mathbf{0}$ & 3 & 10 & \\
\hline \multicolumn{5}{|c|}{$78 \times 10^{-7} 195 \times 10^{-7}$} \\
\hline BHT & $33 \times 10^{-7}$ & $86 \times 10^{-7}$ & ${ }^{7} 181 \times 10-7$ & TNTC \\
\hline C.C. $H_{1}$ & $31 \times 10^{-7}$ & $64 \times 10^{-7}$ & $193 \times 10^{-7}$ & TNTC \\
\hline C.C. $\mathbf{H}_{2}$ & $30 \times 10^{-7}$ & $93 \times 10^{-7}$ & $211 \times 10^{-7}$ & TNTC \\
\hline C.H.T & $34 \times 10^{-7}$ & $80 \times 10$ & $-7206 \times 10^{-7}$ & TNTC \\
\hline C.H.T 3 & $3 \times 10^{-7} 9$ & $90 \times 10^{-7}$ & $200 \times 10^{-7}$ & TNTC \\
\hline
\end{tabular}

control ( $\mathrm{C}$ ), hydrolyzed collagen with collagenase (50 \& $100 \mathrm{mg} / 100 \mathrm{~g}$ meat (C.H.1, C.H.2) , collagenase - trypsin hydrolyzed collagen (C. H. T1, C.H. T2). * $(\mathrm{P} \leq \mathbf{0 . 0 5})$.

TNTC: Too Numerous To Count (TNTC) or Too Many To Counts (TMTC) In samples with very high bacterial concentration, that is not suitable for counting (unable to get accurate counts) .

\section{REFERNCES}

1. Abdelhedi O.; R.,Nasri ; L,,Mora; F., Toldrá ; M . Nasri; and M. Jridi . 2017. Collagenous proteins from black-barred halfbeak skin as a source of gelatin and bioactive peptides. Food Hydrocoll.;70:12333

2. American Public Health Association. .1992. Compendium methods for microbiological examination of foods. ${ }_{2}$ nd ed., Washington, D. $\mathrm{C}$

3. Anand, S. K. ; N. K. Pandey.; C. M. Mahapatra and S. S. Verma 1991. Microbiological quality and shelf life of chicken patties stored at $-18^{\circ} \mathrm{C}$. Indian J. Poult. Sci., 26: 105-108

4. Barthet ,VJ. ; V. Gordonand and J.Daun .2008. Evaluation of a colorimetric method for measuring the content of FFA in marine and vegetable oils. Food Chem. :1064 1068. [Google Scholar]

5. Bhat, Z.F.; V. Pathak, S.A.A.; S.R., Bukhari, Ahmad and H. Bhat. 2011. Quality changes in Chevon harrisa (meat based product) during refrigerated storage. Int. J. Meat Sci., 1: 52-61.CrossRef

6. Caniff, P. editor. AOAC. 1999. International. Official methods of analysis of AOAC international. 16th ed. Gaithersburg, Maryland, USA: AOAC International. [Google Scholar]

7. Duan R.; J. Zhang ; X .Dua ; X. Yao and; K. Konno .2009. Properties of collagen from skin, scale and bone of carp (Cyprinus carpio) Food Chem.;112:702-706. doi: 10.1016/j.foodchem.2008.06.020. [CrossRef] [Google Scholar].

8. Egyptian standard (ES) . 2005. Egyptian Organization for specialization and quality control, Egyptian Standard for fresh meat. Ministry of Industry No. 1522/2005

9. Elkhalifa E. A., Anglemier A. F., Kennick W. H., E. A. and Elgasim 1984.Influence of pre-rigor pressurization on postmortem beef muscle creatine phosphokinase activity and degradation of creatine phosphate and adenosine triphosphate. J. Food Sci.;49:595597. [Google Scholar].

10. Fan, W.; Sun, J.; Chen, Y.; Qiu, J.; Y. Chi ;and Y. Zhang .2009. Effect of chitosan coating on quality and shelf life on silver carp during frozen storage. Food Chem., 115: 66-70 11. Food and Agriculture Organization (FAO) . 1980. Manual of Food Quality Control. FAO, United Nation, Rome, Italy

12. Habbal, E. L. Y. 2000 . Study on the quality control of some frozen meat products. M.V.Sc. Thesis. Fac. Agric. Cairo Univ

13. International Organization for Standardization. 2003 . Microbiology of food and animal feeding stuffs. Horizontal method for the enumeration of microorganisms. Colony count technique at 30C. EN ISO 4833. ISO, Geneva

14. Kim, S. K. and I. Wijesekara .2010. Development and biological activities of marine-derived bioactive peptides: A review. J. Funct. Foods 2, 1-9

15. Lund, M. N.; C. Luxford; L. H. Skibsted and M. J. Davies .2008 . Oxidation of myosin by haem proteins generates myosin radicals and protein cross-links. Biochem. J. 410, $565-$ 574.

16. Nagamallika, E., K. P. Reddy and P. M. Reddy. 2006. Effect of storage on physicchemical microbiological and sensory quality of chicken patties. Indian J. Poult. Sci., 41: 271-274

17. Nam, K. A. ; S. G. You and S. M. Kim .2008. Molecular and physical characteristics of squid (Todarodes pacificus) skin collagens and biological properties of their enzymatic hydrolysates. J. Food Sci. 73, 249-256

18. Nayak, N.K. and V.K. Tanwar . 2004. Effect of tofu addition on physico- 
chemical and storage properties of cooked chicken meat patties. Indian J. Poult. Sci., 39: 142-146

19. Ngo, D. H. ; I. Wijesekara ; T. S. Vo;Ta, Q. Van and S. K. Kim .2011 . Marine foodderived functional ingredients as potential antioxidants in the food industry: An overview. Food Res. Int. 44, 523-529

20. Park, P. J. ; Jung, W. K.; K. S. Nam; F. S. K. Shahidi and Kim. 2001. Purification and characterization of antioxidative peptides from protein hydrolysate of lecithin-free egg yolk. J. Am. Oil Chem. Soc. 78, 651-656

21. Pranoto Y. ; CM. Lee; and HJ. Park. 2007.Characterization of fish gelatin films added with gellan and $\kappa$-carrageenan processing of fish. Int $\mathbf{J}$ Food Sci Technol.;40(5):301-343.

22. Raharjo, S. and J. N. , Sofos .1993. Methodology for measuring malonaldehyde as a product of lipid peroxidation in muscle tissues. A review. Meat Sci., 35: 145-169

23. Rahman M. H. ; M. M. Hossain ; S. M. E. Rahman ; M. R. Amin, and OH. Deog-Hwan . 2015. Evaluation of Physicochemical deterioration and lipid oxidation of beef muscle affected by freeze-thaw cycles. Korean J Food Sci Anim Resour. 35(6): 772 782.Published online 2015 Dec 31. doi: 10.5851/kosfa.2015.35.6.772

24. Rukunudin I. H. ; P. J.White; C. J. ,Bern ; and T. B. Bailey. 1998. A modified method for determining free fatty acids from small soybean sample sizes. J. Am. Oil Chem. Soc.;75:563-568. [Google Scholar].

25. Sabeena Farvin, and K. H. 2014 .Antioxidant activity of Cod (Gadus morhua) protein hydrolysates: In vitro assays and evaluation in $5 \%$ fish oil-in-water emulsion. Food Chem. 149, 326-334

26. Salem, A. M.; R. A. Amin ; and A. S. G. Afifi. 2010. Studies on antimicrobial and antioxidant efficiency of some essential oils in minced beef. J. Am. Sci., 6: 691-700

27. Sallam, K. I.; M.,Ishioroshi and , K. Samejima .2004 Antioxidants and antimicrobial effects of garlic in chicken sausage. Lebensm.-Wiss. Technol. 37, 849855

28. Salman Z. O.; B. M. J. Alwash ; and E. J. Kadhim.2019. Effect of essential oil of cestrum nocturnum flowersl cultivated in iraq as antioxidant and elonation cold storage period of minced meat. Iraqi Journal of Agricultural Sciences:50(2):601-607

29. SAS. 2012. Statistical Analysis System, User's Guide. Statistical. Version 9.1 ${ }^{\text {th }}$ ed. SAS. Inst. Inc. Cary. N.C. USA

30. Senaratne , L. S; and P S.; Kim.2006. Isolation and Characterization of Collagen from Brown Backed toadfish (lagocephalus gloveri) Skin. Bioresource technol 97(2): 191 197

31. Shahidi F. 1994. Seafood Processing byProducts. In: Shahidi F, Botta JR, editors. Seafoods Chemistry, Processing, Technology and Quality. Glasgow: Blackie Academic Professional; pp. 11-26

32. Shantha, N. C. and E. A. Decker. 1994. Rapid, Sensitive iron-based Spectrophotometric Methods for Determination of Peroxide Values of Food Lipids. Journal of AOAC International, 77(2), 422-425

33. Sikorski, Z. E.; A. Kolakowska ; and J. R. Burt. Seafood . 1989. Resources, Nutritional Composition

34. Sudeepa E.S ; H.N.Rashmi ; and N.Bhaskar . 2007.Partial Purification and Characterization of Protease of Bacillus proteolyticus CFR3001 Isolated from Fish Processing Waste and its Antibacterial A.Tamil Selvi Bioresource Technology 98, (Issue 14),P: 2758-2764

35. Verme, S. P. and J. Sahoo .2000 . Improving the Quality of Ground Chevon during Refrigerated Storage by Tocopherol Acetate preblending. Meat Sci., 56:403-413

36. Wasswa, J. ; J.Tang and Gu, X. 2008 .Functional Properties of Grass Carp (tenopharyngodon Idella), nile perch ( Lates Niloticus ) and nile tilapia ( Oreochromis Niloticus ) Skin Hydrolysates. Int. J. Food Prop. 11, 339-350

37. Whittle, K.; R. Hardy ; and G. Hobbs .1990 . Chilled Fish and Fishery Products. In: In: Gormley T., Editor. Chilled foods. The state of the art. New York: Elsevier Applied Science ;. pp. 87-116. [Google Scholar].

38. Wilson, A. 1991. Practical Meat Inspection, Blackwell, Scientific Publication, Oxford. U.K. $5^{\text {th }}$ ed.

39 . Witte, V. C.; G. F. Krause and M. E. ,Baily. 1970 . A new Extraction Method for 
Determining 2-thiobarbituric acid values of pork and beef during storage. J. Food Sci., 35: 582-585

40. Zhang, Z.; G., Li and B ., Shi. 2006.

Physiochemical Properties of Collagen,
Gelatin and Collagen Hydrosylate Derived from Bovine Lime Split Wastes. Journal of the Society of Leather Technologists and Chemists., 90(1):32-28. 